\title{
DEINDUSTRIJALIZACIJA I NJEZIN UTJECAJ NA UBLAŽAVANJE BUDUĆE KRIZE - SLUČAJ EUROPSKE UNIJE
}

\author{
Tomislav Herceg9
}

UDC / UDK: 330.341.426:338.45:(338.124.4:638.252)(4-67EU)

JEL classification / JEL klasifikacija: O14, I15, O52

DOI: https://doi.org/10.22598/pi-be/2020.14.2.89

Preliminary communication / Prethodno prioćenje

Received / Primljeno: August 24, 2020 / 24. kolovoza 2020.

Accepted for publishing / Prihvaćeno za tisak: September 23, 2020 / 23. rujna 2020.

\section{Sažetak}

U Europskoj je uniji prisutan dugotrajni proces deindustrijalizacije. Taj proces je u robnom dijelu nadomješten jeftinijim proizvodima izrađenima u dalekim zemljama s nižim plaćama radnika, ali $i$ radnim $i$ ekološkim standardima, a financijski je nadomješten proizvodnjom u tercijarnim djelatnostima, tj. uslugama. Međutim ovaj rad pokazuje kako su za vrijeme nedavne Velike ekonomske krize zemlje s jačom industrijom brže izlazile iz krize. Formiran je model u kojemu se proučava broj recesijskih kvartala zemalja Europske Unije od 2008. - 2019. godine te kako na njega utječe udio prerađivačke industrije u BDP-u zemalja članica u početnoj godini krize, 2008. Uz to, dodani su indeks kvalitete upravljanja te udio javnoga duga u BDP-u. Analiza je pokazala kako udio prerađivačke industrije u BDP-u uvećan za 1 postotni poen uzrokuje skraćivanje recesije za 0,27 kvartala. Isto tako, na krizu ima utjecaja i država, u vidu kvalitete upravljanja (povećanje indeksa kvalitete upravljanja za 1 skraćuje recesiju za 0,15 kvartala) te manevarskog prostora za poticanje potražnje (svaki postotni poen javnoga duga produžuje recesiju za 0,05 kvartala). Nadalje, analiza je pokazala kako su početni uvjeti 2008. i 2019. godine takvi da bi nova kriza, bez pojave epidemije, trajala $13,5 \%$ dulje nego Velika kriza. Stoga bi se proces deindustrijalizacije trebao promatrati s posebnom pažnjom jer se time, pokazuje se, umanjuje automatska protuciklička snaga ekonomije, posebno važna u trenutcima nadolaska još nezabilježene ekonomske krize uzorkovane epidemijom COVID-19.

Ključne riječi: prerađivačka industrija, Europska unija, velika ekonomska kriza, deindustrijalizacija, indeksi kvalitete upravljanja, COVID-19.

${ }^{9}$ Doc.dr.sc. Tomislav Herceg, docent, Ekonomski fakultet, Sveučilište u Zagrebu, Trg J. F. Kennedyja 6, Zagreb, E-mail: therceg@efzg.hr 


\section{UVOD}

Uoči pojave epidemije bolesti COVID19 postojale su brojne naznake dolaska nove, po nekima još intenzivnije ekonomske krize, npr. An, Jalles, Loungani (2018). Iako se fokus krize u potpunosti preselio na do sada nezabilježenu ekonomsku situaciju privremenog potpunog ekonomskog zastoja, neviđenoga čak i u ratnim periodima, bitno je identificirati dvije ključne stvari. Prvo, kakva bi se kriza (eventualno) dogodila da nije bilo epidemije i drugo, kako olakšati i ubrzati izlaz iz krize.

Ovaj rad će ponuditi odgovor na oba pitanja analizom značaja industrije za gospodarstva Europske Unije. Povijesnom analizom, s kvalitativnim razvrstavanjima zemalja po tipovima deindustrijalizacije, a potom regresijskom analizom utjecaja različitih društveno-ekonomskih varijabli na duljinu trajanja krize, nastojat će se utvrditi je li Europska Unija danas spremnija na izazove krize nego li je to bila 2008., ali isključujući utjecaj epidemije, te testirati hipotezu kako zemlje s većim udjelom prerađivačke industrije lakše izlaze iz krize.

U ovom se radi podvlači teza kako su postojale naznake krize i bez pojave epidemije. Iako je dominantan fokus znanstvene i stručne javnosti trenutno usredotočen na COVID-19 i njegove reperkusije na konjunkturu, neophodno je ukazati i na problem sustava. Naime u situaciji opće krize s mjerama koje su usmjerene na sva poduzeća pomoć dobivaju i takozvana „zombi“ poduzeća, koja više troše nego što stvaraju, i egzistiraju uz pomoć potpora i oprosta dugova (Jiang, Li, Song, 2017). Takvih se poduzeća u Hrvatskoj nakupilo cijelo mnoštvo jer je to omogućio stečajni zakon i predstečajne nagodbe koje, često, tek prolongiraju agoniju.

\section{METODOLOGIJA}

Stadiji razvoja industrije u zemljama Europske Unije analizirani su korištenjem metodoligije koju je utvrdio Lever (1991) razvrstavajući pojedina gospodarstva u 5 glavnih tipovima s ponekim podtipovima. Svaka je zemlja Europske Unije analizirana na temelju ovih kriterija i rezultata sekundarne deskriptivne statističke analize, poput pokrivenosti uvoza izvozom, udjela prerađivačke industrije u BDP-u te promjene toga udjela u godinama.

Model duljine trajanja recesije je baziran na prostornim podacima za sve zemlje Europske Unije (s uključenom Velikom Britanijom koja je u promatranom periodu još bila dijelom Europske Unije), bez Belgije, za koju nedostaju podaci o udjelu prerađivačke industrije u BDP-u. Za broj recesijskih kvartala (REC) uzete su sve kvartalne stope rasta od 2008. - 2018. (44 kvartala, izvor podataka je Eurostat, pristupljeno 16. ožujka 2020.g.) te su pobrojani kvartali s negativnim rastom. Podaci o udjelu javnoga duga u bruto domaćem proizvodu (varijabla JD) za iste zemlje su iz 2008., početne godine krize, te 2019.g.. Indeks kvalitete upravljanja, WDI, kojega čini prosjek pet indeksa Svjetske banke: Kontrola korupcije, Učinkovitost uprave, Kvaliteta regulative, Vladavina prava i Pravo glasa, izračunat je za 2008. i 2019. godinu. Podaci su skinuti sa stranica Svjetske banke: wdi.worldbank.org, 16. ožujka 2020. g. Udio prerađivačke industrije u BDP-u 
(PI) je također uzet za početnu godinu krize, za svih navedenih 27 zemalja, ali i za 2019. g. Varijable PI i JD su izračunate na temelju podataka Eurostata, pristupljeno isoga datuma.

$\mathrm{Na}$ temelju tih podataka provedena je multipla linearna regresijska analiza i provedeni su svi potrebni testovi. Pomoću ocijenjenoga ekonometrijskog modela napravljena je projekcija korištenjem podataka iz 2019. godine.

\section{PREGLED LITERATURE}

Hsieh (2011) je u svojoj je analizi četiri "azijska tigra" pokazao kako postoji pozitivna kauzalna veza između rasta sektora prerađivačke industrije i rasta bruto domaćega proizvoda. Također je utvrdio kako budućnost ubrzanih stopa rasta leži u razvoju visokokvalitetnih usluga vezanih uz prerađivačku industriju što se opet vezuje uz koncept Industrije 4.0. Ovo je istraživanje dalo poticaj za istraživanjem može li se i u Europskoj uniji i Hrvatskoj utvrditi slična veza, te ako može, kojeg je smjera djelovanja. Möller (2010) je uočio kako je za vrijeme velike recesije u Njemačkoj prerađivačka industrija, iako snažno pogođena, ,gomilala“ radnu snagu kako ne bi izgubila dobre i iskusne radnike. Na taj je način zadržala znanje radika, a ekonomija je zadržala potrošački potencijal stanovništva te na taj način pomogla oporavku ekonomije.

Kratkov (2011) uočava kako zemlje sa značajnijim omjerom industrije naspram trgovine brže izlaze iz krize. Zemlje u kojima je taj omjer slabiji puno teže vraćaju zaposlene u trgovini na posao.

Siddiqui (2009) je analizirao japanske recesije od pedesetih godina 20. st. do 2009. te je uočio kako prerađivačka industrija pomaže ubrzanom oporavku, pogotovo ako plaće rastu sporije od produktivnosti. Ako rast plaća prati rast produktivnosti tada se antirecesijski potencijal prerađivačke industrije gotovo eliminira, ali se događa povratna veza: recesija uzrokuje pritisak na zaustavljanje rasta plaća u cjelini i popravljanje omjera plaća i produktivnosti što u narednim godinama utječe na brži oporavak, ali ne i za vrijeme same recesije.

\section{RAZVOJ PRERAĐIVAČKE INDUSTRIJE U ZEMLJAMA EUROPSKE UNIJE}

Industrija je prvom industrijskom revolucijom i izumom parnog stroja Jamesa Watta koncem 18. stoljeća počela biti značajan čimbenik gospodarstava svijeta, a tek su industrijalizacijom zemlje počele bilježiti stope rasta veće od nule. Proizvodnja je porasla ne samo u prerađivačkoj industriji, već i u rudarstvu i vađenju te u poljoprivredi gdje su primjene novih tehnika povećale prinose, nužne za brzo rastuće stanovništvo.

U zemljama Europske unije i Hrvatskoj udio industrije je prvo rastao, a potom opadao nauštrb sektora usluga. Ipak, i danas je u modernim gospodarstvima industrijski sektor važan gospodarski sektor, iako rijetko kada prelazi trećinu ukupnog bruto domaćeg proizvoda. Razvoj industrije je bio posebno naglašen kao motor razvoja u zemljama 
sjeverne i središnje Europske unije, no za jug Europske unije (Grčka, Italija, Španjolska, Francuska i Portugal) industrija nije imalo tako velik značaj za razvoj. Te zemlje dobar dio svoje gospodarske aktivnosti obavljaju direktno ili indirektno vezano uz turizam. Međutim velika svjetska gospodarska kriza pokazala je kako se zemlje europskoga juga teže nose s krizom. Stoga se postavlja pitanje: jesu li zemlje europskoga sjevera bile imunije na recesiju zbog snažnije prerađivačke industrije? S obzirom na to postavljena je glavna hipoteza ovoga rada: duljina trajanja krize u zemljama Europske Unije i Hrvatskoj povezana je s udjelom prerađivačke industrije u BDP-u..

Tokom dvadesetoga stoljeća većina je zemalja današnje Europske Unije dosegla vrhunac udjela industrijske proizvodnje u bruto domaćem proizvodu, a taj je udio jačanjem sektora usluga postepeno opadao ili stagnirao. Industrija se sastoji od rudarstva i vađenja, prerađivačke industrije i energetike, no najznačajniji dio industrije čini prerađivačka industrija.

Prerađivačka je industrija počela svoj razvoj industrijskom revolucijom. Do tada se sva proizvodnja odvijala u zanatskim radionicama ili manufakturama ${ }^{10}$, preteči tvornica. Nakon izuma parnoga stroja, energiju vode i ljudi zamjenjivalo se energijom drva ili ugljena. Taj je proces započeo u Engleskoj, a vrlo brzo se proširio Njemačkom, Nizozemskom i Francuskom te doskora i ostalim regijama bogatima ugljenom i željeznom rudom: Šleskom (današnja južna Poljska), Češkom i dijelovima današnje Austrije.

Industrijski je razvoj spomenutih zemalja bio dug i postepen. Gradili su se plovni kanali (npr. spoj Sredozmenoga mora i Atlantika južnom Francuskom, mreža kanala u Engleskoj, Nizozemskoj, Pruskoj) i željeznica kao kopnena potpora razvoju i napretku industrije, a to je promijenilo izgled gradova. Zbog velikih je gužvi u gradskom prometu sagrađena i prva podzemna željeznica u Londonu sredinom 19. stoljeća, koju je potom slijedila budimpeštanska te mnoge druge.

Zemlje i područja koja nisu bila bogata rudama imala su puno sporiji razvitak, a neke od njih, npr. zemlje bivše Jugoslavije, industrijalizirane su tek nakon 2. Svjetskog rata. Zemlje koje su imale kolonijalna carstva (Velika Britanija, Francuska, Nizozemska, Portugal i Španjolska) iscrpljivali su svoje kolonije koristivši njihove resurse, a prerađivali su ih u matičnim zemljama. Te su zemlje bile jednonacionalne te su se stoga ujednačenije razvijale.

Austrougarska, Rusija i Pruska (od 19. stoljeća ujedinjena u Njemačku) nisu imale kolonije, ali su se širila nauštrb susjeda. Ova su carstva bila uglavnom višenacionalna uz dominacije jedne ili dvije nacije, a ostale su pokrajine, današnje države Europske unije, bile izvor resursa. ${ }^{11}$

${ }^{10}$ Lat. manus, us, f. - ruka (ili četa), facio, facere, feci, factum - činiti: proizvodnja rukama, prije izuma parnoga stroja. Engleski pojam "manufacturing" nema veze s hrvatskim pojmom manufaktura jer je "manufacturing" prerađivačka industrija. jer je manufaktura $\mathrm{u}$ anglosaksonskim zemljama imala kontinuitet razvoja i taj se naziv izumom stroja jednostavno prenio na nova, parom pogonjena postrojenja.

${ }^{11}$ Pruska, a potom Njemačka, je vladala velikim dijelom današnje Poljske, koju su raskomadali krajem 17. stoljeća s Austrijom i Rusijom. Od 19. stoljeća Njemačka je 
Hrvatska je u industrijskom razvoju Europe bila na periferiji te je više nalikovala koloniji za izvlačenje resursa. Primjer za to je vidljiv u razvoju manufaktura i željeznica u Hrvatskoj. Dok se manufaktura razvijala u zemljama Europe, Hrvatska se borila s osmanlijskom invazijom. Feudalci su resurse trošili na ratove s Turcima, a ne na razvoj manufakture. Naprimjer dvije najveće velikaške obitelji u Hrvatskoj, Zrinski i Frankopani, prije oduzimanja sve imovine 1671.g., već su u znatnoj mjeri bili iscrpili svoja vlastelinstva i imali su ogromne dugove (Mirković, 2001).

Oslobađanjem od Turaka pokušan je razvoj manufaktura u Hrvatskoj u 18. stoljeću. Otvarane su suknare u Zagrebu, Vukovaru, Trakošćanu i Stenjevcu, lončarska i pećarska radionica u Križevcima, ljevaonica bakra u Samoboru, staklane u Našicama i Zagrebu, svilana u Osijeku, kožarska manufaktura u Kutjevu, željezara u Bregani, itd. Sve su manufakture trajale svega nekoliko godina, najviše 25 , i sve su imale iste probleme: nedovoljno educirani radnici i prejaka konkurencija austrijskih i čeških proizvođača. U okolnostima takve (ne)razvijenosti gospodarske aktivnosti, željeznica se nije gradila za hrvatske potrebe, već za potrebe drugih zemalja u Austrougarskoj te je bilo i za očekivati da njezina gradnja, tek 1867., neće pogodovati Hrvatskoj. Transverzalni željeznički pravci su uzrokovali slabljenje Slavonije jer je željeznica išla preko Budimpešte. Oslabila je i Lika jer je zamrla trgovina prema moru od Karlovca (Mirković, 2001).

Ulaskom Hrvatske u Kraljevinu SHS, kasnije Jugoslaviju, industrijalizacija je i dalje bila vrlo spora, a Jugoslavija je 1945. godine još uvijek bila ruralna zemlja. Tek je planskom ekonomijom Hrvatska industrijalizirana; tako je u Hrvatskoj 1952. godine rudarstvo i industrija činilo $23,6 \%$ BDP-a, a 1989. Čak 38,7\%, od čega se najveći dio odnosio na prerađivačku industriju. $U$ istom je razdoblju udio poljoprivrede u BDP-u pao s 27,1 na $14,0 \%$ (Družić, 1997)

Nakon osamostaljenja Hrvatske industrijska je proizvodnja drastično opala te je 1994. godine proizvodnja prerađivačke industrije bilo dvostruko manja nego pet godina prije toga. Uzroci tomu su višestruki, a najznačajniji su kleptokracijska privatizacija, ratna razaranja i tromost velikih sustava koji nisu, poslujući u netržinim uvjetima, bili u mogućnostima prilagoditi se slobodnoj razmjeni i optimizirati alokaciju resursa. Do kraja devedesetih godina stanje u industriji je bilo sve teže, da bi se sredinom 2000-ih blago oporavila, no početkom krize 2008. g. proizvodnja prerađivačke industrije je opet snažno opala. Uzrok tome je opadanje inozemne potražnje.

Posljedice deindustrijalizacijskog procesa su drastičan pad pokrivenosti uvoza izvozom; taj je postotak rastao od pedesetih godina sa sedamdesetak posto na preko $100 \%$ šezdesetih, sve do otprilike $90 \%$ sredinom osamdesetih. Nakon rata pokrivenost uvoza izvozom naglo opada, a ulaskom u novo tisućljeće svake je godine bila manja od $50 \%$ (Družić, 2004). Ipak, od 2014. g., promatrajući objedinjeno saldo računa trgovine robama i uslugama (koje uključuju turizam), hrvatska je platna bilanca uravnotežena i čak je u blagom suficitu.

kontrolirala i dijelove Francuske. Rusija je gospodarila Finskom, pribaltičkim zemljama, dijelovima Poljske, Ukrajinom i Bjelorusijom, a Habsburška monarhija cijelim nizom zemalja srednje i istočne Europe. 


\section{VRSTE DEINDUSTRIJALIZACIJE U EUROPSKOJ UNIJI}

Unatoč razlici u brzini razvoja industrije, koja se u Engleskoj razvijala više od stoljeća i pol, a u Hrvatskoj, Slovačkoj, Poljskoj, Mađarskoj, Bugarskoj i Rumunjskoj četrdesetak godina, osnovne osobine razvoja industrije su slične u svim zemljama, samo se trajanje industrijalizacije proteže kroz duže ili kraće razdoblje (Slika 1). Zemlje srednje i istočne Europe, koje su nakon 1945. godine postale socijalističke ekonomije, proces industrijalizacije su provodile planski i ubrzano, za razliku od zapadnih i sjevernih zemalja Europske unije u kojima se industrija razvijala samostalno, pod utjecajem tržišta. Stoga je proces industrijalizacije samo na prvi pogled vrlo sličan $u$ te dvije skupine zemalja; dok su se na zapadu razvijale industrije koje su bile profitno orijentirane i ciljale na široku potrošnju, u socijalističkim se zemljama intenzivnije razvijalo tešku industriju koja je bila nužna za razvoj osnovne infrastrukture te naoružanja. Tek se početkom šezdesetih godina dolaskom Nikite Hruščova na čelo Sovjetskoga Saveza prerađivačka industrija orijentirala prema potrošačkim dobrima.

Slika 1. Shematski prikaz kretanje broja zaposlenih u poljoprivredi, industriji i uslugama

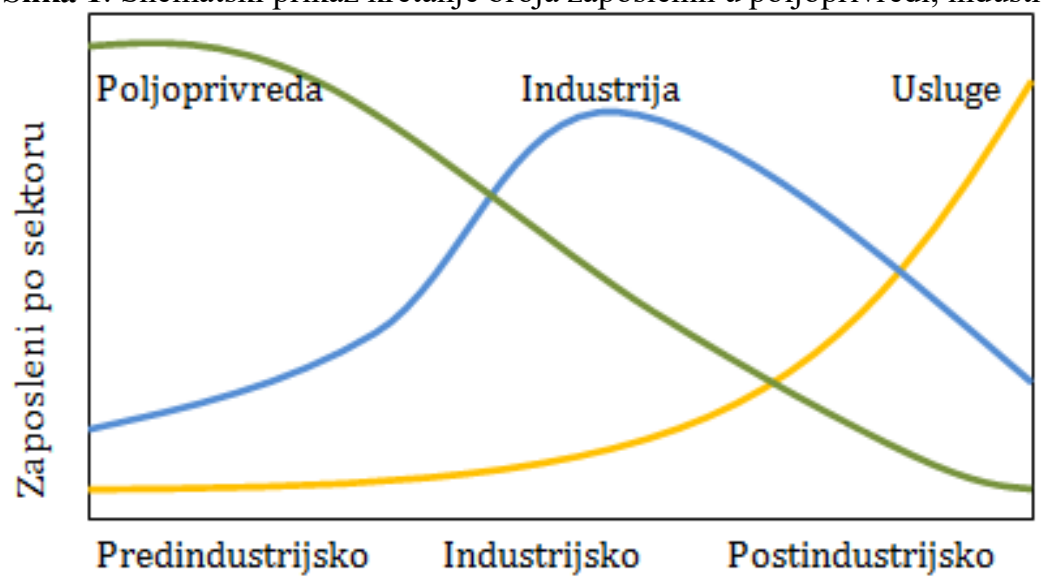

\section{RAZDOBLJE}

Izvor: Družić et al. (2003)

Na Slici 1 prikazan je opći slučaj razvoja industrije. Može se vidjeti kako na početku postoji velika zaliha radne snage ${ }^{12} \mathrm{u}$ poljoprivredi. To je predindustrijsko razdoblje. Porastom udjela zaposlenika u industriji opada broj zaposlenih u primarnim

12 Također se može promatrati i kriterij udjela ukupne proizvodnje industrije u bruto domaćem proizvodu. Po tom kriteriju ne moraju sve zemlje biti na istom stupnju razvoja industrije kao i prema kriteriju broja zaposlenika. Primjer za to je automobilska industrija koja je sve manje radno intenzivna i sve više robotizirana. 
djelatnostima. Taj proces se zove industrijilazacijom, a njime se dolazi do industrijskoga razdoblja. Nakon toga napretkom tehnologije opada broj zaposlenih u industriji nauštrb sektora usluga te se dolazi do postindustrijskog razdoblja, a proces opadanja zaposlenika u prerađivačkoj industriji se naziva dezindustrijalizacijom.

Može se zaključiti kako društvo prolazi kroz dva procesa: proces industrijalizacije i proces dezindustrijalizacije. Suočeni s niskom pokrivenošću uvoza izvozom, vjerojatno će se doskora detaljnije razmatrati i proces reindustrijalizacije, koja je jedini pravi odgovor na problem dužničke krize i konstantnog deficita tekućeg računa platne bilance.

Proces industrijalizacije Crkvenac (1993) dijeli na pet faza. Prva je faza početna industrijalizacija $u$ kojoj se investiranje preusmjerava $u$ industriju. Sljedeća je faza kvantitativna ekspanzija industrije u kojoj se vide rezultati početne faze: pojačana urbanizacija i daljnje ulaganje u industriju. Treća je faza faza korekcija grešaka u prethodne dvije faze te otvaranje tržišta međunarodnim tokovima. Četvrta je faza stabilizacija. Tada se zemlja profilira u područjima u kojima ima komparativnu prednost, a proizvodnja se sofisticira povećanjem tehnološke opremljenosti i produktivnosti rada. Konačno, peta faza je faza međusektorske diverzifikacije industrije. $U$ toj se fazi industrija u potpunosti osuvremenjuje. Ova faza je i početak dezindustrijalizacije jer uslužni sektor postaje sve jači.

Sve zemlje Europske unije i Hrvatska su u zadnjem, postindustrijskom stadiju razvoja industrije, što znači da su zemlje više ili manje odmakle u procesu deindustrijalizacije. Stoga će se posebna pozornost posvetiti analizi procesa deindustrijalizacije i postindustrijskih gospodarstava. U svrhu preciznije analize potrebno je razvrstati zemlje Europske Unije s obzirom na razvoj i značenje industrije u njihovim gospodarstvima. Lever (1991) proučava industrijsku proizvodnju zemalja OECD-a u 20. stoljeću te je podijelio zemlje u pet slučajeva s obzirom na promjene udjela industrijske proizvodnje u bruto domaćem proizvodu, promjene rasta prerađivačke industrije te načine uravnoteženja platne bilance (Tablica 1).

Tablica 1. Kriteriji za razvrstavanje postindustrijskih zemalja po deindustrijalizacijskom tipu

\begin{tabular}{|c|c|c|c|c|l|}
\hline $\begin{array}{c}\text { Tip } \\
\text { deindustrija- } \\
\text { lizacije }\end{array}$ & $\begin{array}{c}\text { Udio } \\
\text { prerađivačke } \\
\text { industrije u } \\
\text { BDP-u }\end{array}$ & $\begin{array}{c}\text { Rast } \\
\text { proizvodnje } \\
\text { prerađivačke } \\
\text { industrije }\end{array}$ & $\begin{array}{c}\text { Vanjski } \\
\text { dug }\end{array}$ & $\begin{array}{c}\text { Neto } \\
\text { izvoz }\end{array}$ & $\begin{array}{c}\text { Kompenzacija } \\
\text { deficita izvoza } \\
\text { roba }\end{array}$ \\
\hline I & PI/BDP & gPI & VD & NI & \\
\hline II & $\downarrow$ & $<0$ & $\uparrow$ & $?$ & \\
\hline III & $\downarrow$ & $>0$ & 0 & $>0$ & \\
\hline IV-a & $\downarrow$ & $>0$ & $\circ$ & $<0$ & -izvoz usluga \\
\hline
\end{tabular}




\begin{tabular}{|c|c|c|c|c|c|}
\hline $\begin{array}{c}\text { Tip } \\
\text { deindustrija- } \\
\text { lizacije }\end{array}$ & $\begin{array}{c}\text { Udio } \\
\text { prerađivačke } \\
\text { industrije u } \\
\text { BDP-u }\end{array}$ & $\begin{array}{c}\text { Rast } \\
\text { proizvodnje } \\
\text { prerađivačke } \\
\text { industrije }\end{array}$ & $\begin{array}{c}\text { Vanjski } \\
\text { dug }\end{array}$ & $\begin{array}{c}\text { Neto } \\
\text { izvoz }\end{array}$ & $\begin{array}{c}\text { Kompenzacija } \\
\text { deficita izvoza } \\
\text { roba }\end{array}$ \\
\hline IV-b & $\downarrow$ & $\geq 0$ & 0 & $<0$ & $\begin{array}{l}\text { inozemno } \\
\text { zaduživanje }\end{array}$ \\
\hline $\mathrm{V}$ & $\rightarrow, \uparrow$ & $>0$ & $\circ$ & $>0$ & \\
\hline
\end{tabular}

Izvor: Izrada autora prema Lever (1991)

Prvi je oblik kratkoročno smanjenje industrijske proizvodnje. Na prvi se mah ne može znati radi li se o ciklusu ili o dugoročnom trendu. Druga vrsta je slučaj kada udio industrije u bruto domaćem proizvodu konstantno opada nauštrb sektora usluga. Međutim ako stopa rasta industrijske proizvodnje nije negativna može se raditi tek o povećanju produktivnosti radnika, a ne o deindustrijalizaciji. Ako je pak stopa rasta industrije nedovoljna da se robnim izvozom pokrije robni uvoz, tada se dolazi do trećeg, ozbiljnijeg slučaja opadanja industrijske aktivnosti. Tada se nedovoljna industrijska proizvodnja može kompenzirati izvozom usluga, npr. jakom orijentacijom prema turizmu. Ako pak ne postoji dobra strategija razvoja sektora izvozno orijentiranih usluga, tada se radi o četvrtom, najmanje poželjnom scenariju, a to je slučaj kada izvoz roba i usluga zajedno ne pokriva ukupni uvoz roba i usluga $i$ to kroz duži vremenski period. $U$ tom se slučaju deficit tekućeg računa platne bilance može namiriti bilo zaduživanjem, čime se povećava vanjski dug, bilo priljevom stranih investicija, poželjnijim oblikom uravnoteženja platne bilance.

Peti je oblik specifičan i razlikuje se od drugih oblika. To je slučaj u kojemu industrijska proizvodnja u svom udjelu u bruto domaćem proizvodu stagnira ili raste. Taj oblik ne spada u deindustrijalizacijski već reindustrijalizacijski ili stagnacijski proces. Drugim riječima, zemlja petog tipa je završila proces transformacije društva u društvo usluga, no zadržala je razinu industrije na istoj razini ili je lagano povećava. Taj proces je bitno drugačiji od industrijalizacije jer industrijalizacija kreće iz agrarnoga društva, a reindustrijalizacija iz društva usluga.

Proces smanjenja udjela industrijske proizvodnje u ukupnoj proizvodnji u Europi se različito reflektirao na različite ekonomije i u različitim situacijama. Lever (1991) je dao pregled deindustrijalizacije za zemlje OECD-a do 1990. godine, a u ovom će se radu nastaviti analiza za razdoblje od 1991. do 2018. godine.

U skladu s kriterijima za tipizaciju industrijalizacijskoga tipa danima Tablicom 1., analizirana su sva gospodarstva Europske unije i Hrvatske od 1991.-2018.g. Promatrani su podaci o rastu BDP-a i prerađivačke industrije, udjelu prerađivačke industrije u BDP-u, neto izvozu, javnome dugu te proračunskom deficitu, a izvor su UNStats, Eurostat i Međunarodni monetarni fond. Dobiveni su rezultati iskazani Tablicom 2. 
Tablica 2. Tip deindustrijalizacije u zemljama Europske unije u razdoblju od 1991. 2018. godine.

\begin{tabular}{|l|l|l|l|}
\hline Zemlja & Tip & Zemlja & Tip \\
\hline Austrija & 5 & Finska & 5 \\
\hline Belgija & 2 & Francuska & 3 \\
\hline Bugarska & $4 \mathrm{a}$ & Grčka & $4 \mathrm{~b}$ \\
\hline Cipar & $3-4 \mathrm{a}$ & Hrvatska & $4 \mathrm{~b}$ \\
\hline Češka & $4 \mathrm{a}-3-5$ & Irska & $2-1-4$ \\
\hline Danska & 2 & Italija & $2-3-4 \mathrm{~b}$ \\
\hline Estonija & $4 \mathrm{a}$ & Latvija & $4 \mathrm{a}$ \\
\hline Litva & $4 \mathrm{a}$ & Portugal & $4 \mathrm{~b}$ \\
\hline Luksemburg & 2 & Rumunjska & $4 \mathrm{a}$ \\
\hline Mađarska & $4 \mathrm{~b}$ & Slovačka & $4 \mathrm{a}$ \\
\hline Malta & 3 & Slovenija & $3-4 \mathrm{a}-4 \mathrm{~b}$ \\
\hline Nizozemska & 2 & Španjolska & $4 \mathrm{~b}$ \\
\hline Njemačka & 5 & Švedska & 2 \\
\hline Poljska & $4 \mathrm{a}$ & Ujedinjeno kraljevstvo & 3 \\
\hline
\end{tabular}

Izvor: Vlastita analiza

Austrija je do 1991. bila primjer deindustrijalizacije trećeg tipa jer se njezin udio industrije u bruto domaćem proizvodu smanjio, uz vrlo spor godišnji porast industrijske proizvodnje. Uzrok tome je rigidnija imigracijska politika koja je bila smanjila broj radnika u industrijskom sektoru. Međutim, Austrija je vrlo uspješno robni izvoz bila nadomjestila izvozom usluga, poglavito turističkim i financijskim uslugama. U protekla dva desetljeća Austrija je uspjela stabilizirati udio prerađivačke industrije na oko $20 \%$ BDP-a i povećati neto izvoz, te sada pripada reindustrijalizacijskom tipu 5, kao i Finska. Međutim slabljenje Nokie na svjetskom tržištu mobilnih telefona uslijed neprilagođavanja zahtjevima tržišta ("pametni telefoni"), dovelo je do stagnacije reindustrijalizacije Finske.

Njemačka, Nizozemska i Švedska su bili primjeri za industrijsku kontrakciju drugog tipa. U njima se udio industrije u BDP-u smanjivao, ali je proizvodnja dovoljno rasla uslijed povećanja produktivnosti i smanjenja broja industrijskih radnika rasla te je neto izvoz ostao pozitivan. Nakon 1994. Njemačka je stabilizirala udio industrije u BDPu na oko $22 \%$ uz rastući suficit u izvozu roba i usluga te je stoga prešla u peti, najpovoljniji postindustrijski tip. odnosno porast industrijske proizvodnje.

Prije početka tranzicije socijalističke su zemlje imale vrlo visok udio prerađivačke industrije u BDP-u. Poslije 1991. te su zemlje doživjele veliki pad udjela 
prerađivačke industrije u BDP-u, no nakon toga su se počele različito razvijati. Bugarska, Rumunjska, pribaltičke zemlje, Poljska i Slovačka imaju konstantan pad udjela prerađivačke industrije u BDP-u i ne uspijevaju izvozom pokriti uvoz, no to kompenziraju izravnim stranim ulaganjima. Stoga su te zemlje svrstane u tip 4a. Hrvatska i Mađarska su imale sličnu situaciju, ali uslijed nedovoljnih stranih ulaganja gomilale su deficite te su danas vrlo zadužene zemlje tipa 4b. Hrvatska je od 2000. do 2010. godine smanjila udio prerađivačke industrije u BDP-u s preko $20 \%$ na svega $16 \%$, uz veliko vanjsko i javno zaduživanje. 2011. g. taj je omjer pao na 14,1\% (prema podacima Eurostat-a) i potom se stabilizirao na $15 \%$ uz postepeno opadanje udjela javnoga duga u BDP-u i uravnoteženje platne bilance.

Slovenija, koja je krenula iz znatno bolje pozicije (tip 3-4a) pokrivala je male deficite robnoga izvoza izvozom usluga i izravnim stranim ulaganjima, no kao posljedica krize Slovenija je naglo povećavala javni dug te se i ona polako približila tipu 4b. Kako se pokazalo da je taj pad i povećanje duga kratkoga vijeka, tako se moglo utvrditi da se radi o kratkoročnoj deindustrijalizaciji tipa 1.

Češka je imala pozitivniji trend. Naime nakon pada udjela prerađivačke industrije u BDP-u početkom devedesetih, te deficita u međunarodnoj razmjeni, Češka je taj deficit postepeno uspjela pokrivati priljevom stranih ulaganja, da bi potom, ulaskom u Europsku uniju, zadržala udio industrije na oko 26\% BDP-a ostvarujući pozitivan neto izvoz roba i usluga. Time se Češka svrstala u najpovoljniji, 5. tip, reindustrijalizaciju.

Luksemburg i Danska su se do 1990. godine svrstavale u industrijalizacijski tip 5, odnosno zemlje u kojima nema daljnje deindustrijalizacije. U tim zemljama je broj radnika u prerađivačkoj industriji dugi niz godina bio stabilan uz stalan porast industrijske proizvodnje. Nakon 1990. udio prerađivačke industrije u BDP-u se postepeno smanjivao, ali je neto izvoz i dalje bio pozitivan te su Luksemburg i Danska prešle u denidustrijalizacijski tip 2, kojemu pripada i Belgija. Ipak, ove zemlje imaju vrlo nizak udio prerađivačke industrije u BDP-u (6-14\%).

Francuska i Velika Britanija pripadaju deindustrijalizacijskom tipu 3 jer nedovoljan robni izvoz nadomještaju izvozom usluga, poglavito financijskih. Za obje je zemlje karakterističan malen udio prerađivačke industrije u BDP-u (oko 11\%). Kretanja u posljednjim kriznim godinama ukazuju na to da bi se zemlje mogle približiti tipu $4 \mathrm{~b}$.

Mediteranske zemlje poput Španjolske, Grčke i Portugala nemaju jaku prerađivačku industriju (oko 10\% BDP-a), ali ona je dodatno oslabljena Velikom krizom koju je pojačala i stagnacija izvoza turističkih usluga te su prešle iz tipa 3 (kompenzacija robnoga deficita razmjene izvozom turističkih usluga) u tip 4 b deindustrijalizacije (kompenzacija robnoga deficita zaduživanjem). Italija, koja također znatan dio svoje ekonomske aktivnosti temelji na turizmu, razlikuje se od ostalih zemalja Sredozemlja jer ima relativno jaku industriju; Tomaševski (2011) zaključuje kako se u institucijama Europske unije na talijanski javni dug gledalo blagonaklonjenije jer "Italija ipak proizvodi". Ipak, prerađivačka je industrija u Italiji u protekla dva desetljeća sve više slabila, smanjujući udio prerađivačke industrije u BDP-u s $22 \%$ na $16 \%$ uz opadanje neto izvoza koji je od 2005. godine negativan, a kompenzirala ga je zaduživanjem. Stoga je Italija u samo 8 godina prešla iz povoljnoga tipa 2 u najnepovoljniji deindustrijalizacijski tip 4 b. 
Prva vrsta smanjenja industrijske proizvodnje je pogodila većinu europskih zemalja za vrijeme krizne 2009. godine, no slučaj Irske, koja je krenula iz deindustrijalizacijskog tipa 2 , pokazuje da se oporavak industrije neće moći očekivati u kratkom roku u dijelu europskih zemalja te se radi o ozbiljnijem problemu. To znači da se promjene koje se sada čine kao da su deindustrijalizacijski tip 1 u budućnosti pokažu ozbiljnijim slučajem deindustrijalizacije tipa $4 \mathrm{~b}$.

Epidemijski uvjetovana kriza je promijenila ekonomsku paradigmu i pokazala Europi kako je opasno ovisiti o uvoznoj robi. Stoga se mnoge zemlje vraćaju poticanju industrije, pa čak i podržavljavanjem prethodno privatiziranih poduzeća, a takva bi promjena ekonomskih stavova mogla povoljno utjecati na industrijalizaciju u Europi, uz snažnu implementaciju širokog spektra znanja stečenoga o Industriji 4.0. Stoga poticaj za industrijalizaciju više ne leži samo u pretpostavci o antirecesijskom učinku prerađivačke industrije, već i u goloj činjenici potrebe za snabdijevanjem robama o kojima je opasno biti uvozno ovisan, poput hrane, lijekova, ostale medicinske opreme, jednostavnih uređaja i slično.

Slika 2. Kretanje udjela u prerađivačke industrije u zemljama Europske unije (prvi kvartali od 2007. - 2019.)
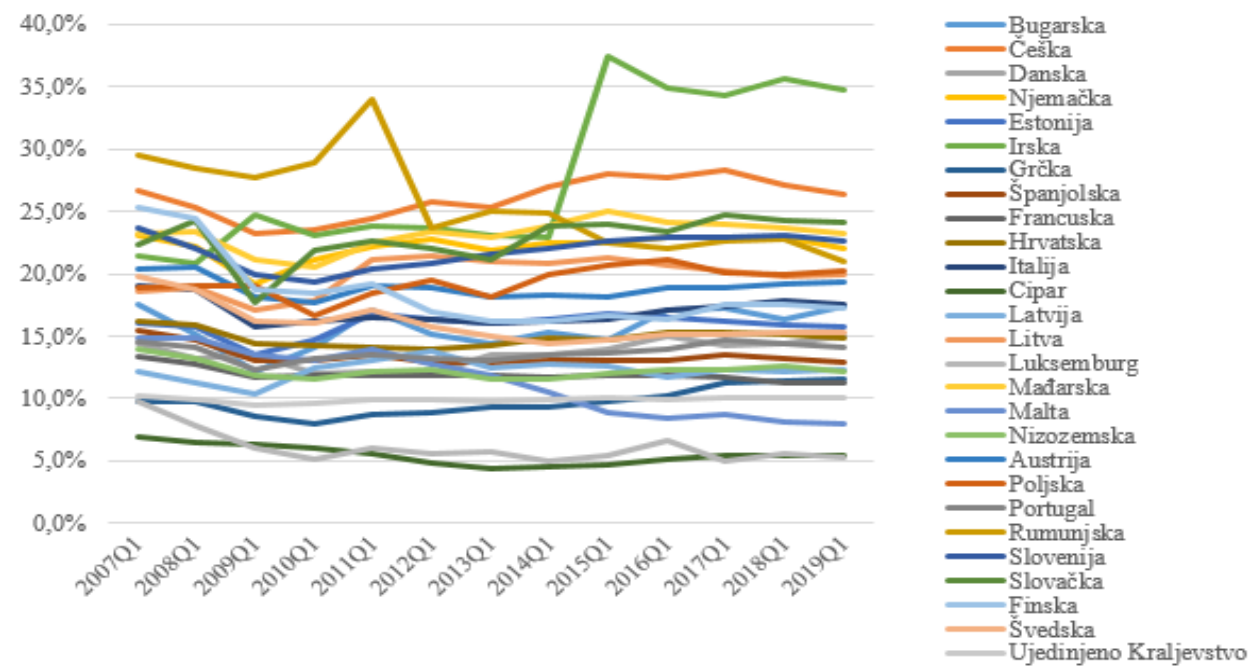

Velik broj zemalja Europske unije se 2008. približavao najcrnjem deindustrijalizacijskom scenariju, tipu 4 (a $\mathrm{i}$ b) s opadajućim udjelom prerađivačke industrije u BDP-u (Slika 2). Međutim na istoj se slici vidi blaga stagnacija toga pada nakon krize što daje optimizam kako su zemlje naučile što deindustrijalizacija čini godpodarstvu. Ipak, vrlo rijetko se uočava pojava industrijalizacije što pokazuje kako zemlje nisu uspjele doći u bolju poziciju, već samo zadržavaju postojeću.

Posljedice toga su dalekosežne jer tip deindustrijalizacije $4 \mathrm{~b}$ znači da je izvoz manji od uvoza uslijed oslabljene prerađivačke industrije. Time se pogoršava stanje 
tekućeg računa platne bilance što povlači potrebu za uravnoteženjem platne bilance kapitalnim priljevom. Ako taj priljev nastaje zaduživanjem, povećava se vanjski dug zemlje. Isto tako, prema teoriji dvostrukih deficita (twin deficits), deficit tekućeg računa platne bilance je povezan i s deficitom proračuna što povećava i javni dug. Porastom javnoga duga smanjuju se mogućnosti države za intervenciju jer je uslijed opadanja kreditnoga rejtinga zaduživanje sve skuplje.

Osnovni je problem u tome što prerađivačku industriju uništava uvoz iz azijskih zemalja u kojima su upitna prava radnika i zaštita okoliša, a u zemljama Europske unije postoje strogi propisi kojima se štite oboje, istovremeno smanjujući konkurentnost vlastite proizvodnje. Stoga je potrebno tržište urediti tako da se na njemu nalaze samo oni proizvodi koji su proizvedeni pri istim standardima zaštite okoliša i prava radnika (Mencinger, 2012).

\section{ANALIZA UTJECAJA UDJELA PRERAĐIVAČKE INDUSTRIJE U BDP-U NA DULJINU TRAJANJA RECESIJE U EUROPSKOJ UNIJI}

Promatrajući gospodarstva središnje i sjeverne Europske unije te zemlje europskoga Sredozemlja može se uočiti kako zemlje poput Italije, Grčke, Španjolske i Portugala imaju manji udio prerađivačke industrije u BDP-u od prosjeka Europske unije. Također se može vidjeti kako je spomenute zemlje europskoga juga Velika kriza teže pogodila nego li je to slučaj sa zemljama sjevera, uz iznimku Irske. Stoga se postavlja istraživačko pitanje: može li se te dvije pojave, udio prerađivačke industrije u BDP-u te ekonomska kriza, dovesti u vezu? Iako je Velika ekonomska kriza započela na tržištu nekretnina i financijskom tržištu SAD-a, a Europom se proširila uslijed velike zaduženosti EU članica, pitanje je bi li se navedeno dogodilo da su se promatrane ekonomije snažnije oslanjale na realni sektor te time smanjile rizik ovako duboke ekonomske, a time i političke i društvene krize. Ovom istraživačkom hipotezom se želi testirati upravo to, no namjera toga istraživanja nije ponuditi jedinstveni lijek za izlazak iz krize Europske unije već ukazati na jedan od brojnih faktora kojim se ta kriza mogla umanjiti i, što je najznačajnije, jesu li se zemlje Europske Unije pripremile za nadolazeću krizu. Hsieh (2011) je utvrdio utvrdio kako takva veza postoji

$\mathrm{Na}$ temelju kvalitativne analize odnosa prerađivačke industrije i gospodarskoga pada u zemljama Europske unije i Hrvatske u prethodnom dijelu ovoga rada, te na temelju Hsievljevog i drugih sličnih radova, postavljena je glavna hipoteza u ovome radu. Tom se hipotezom tvrdi kako je za vrijeme aktualne krize prerađivačka industrija imala protuciklički utjecaj u zemljama Europske unije i Hrvatskoj. Ovu će se hipotezu analizirati ekonometrijskim modelom kojim će se nastojati dovesti u vezu duljina trajanja krize i udio prerađivačke industrije u BDP-u promatranih zemalja. Međutim kako se u modelu ne bi pojavila pristranost uslijed ispuštenih varijabli, u model će se uvrstiti i ostali pokazatelji.

U razmatranje je uzeto tri pokazatelja. Prvi pokazatelj je indeks kvalitete upravljanja kojeg za sve zemlje godišnje objavljuje svjetska banka, a sastoji se od šest indeksa kojima se mjere razni segmenti kvalitete upravljanja, od slobode govora do 
korupcije. Korištenje pokazatelja kvalitete upravljanja i ekonomskih sloboda je učestalo u analizama gospodarskoga rasta i ukupne proizvodnosti čimbenika, a brojni su autori (npr. Campos, Coricelli, 2000, El-Mattrawy, 2006) zaključili kako je kvaliteta upravljanja snažno pozitivno korelirana s gospodarski napretkom.

Drugi je pokazatelj postotak javnoga duga u BDP-. Naime prema keynesijanskoj teoriji država treba za vrijeme krize poticati rast povećanom potrošnjom države kako bi se povećala agregatna potražnja. Ta je teorija imala uspjeha za vrijeme velike krize dvadesetih i tridesetih godina 20. stoljeća. Međutim u proteklim se desetljećima događalo suprotno: zemlje su povećavale javni dug za vrijeme ekspanzije, kada bi se dugovi trebali vraćati. Stoga su mnoge zemlje posljednju globalnu recesiju dočekale prezadužene bez prostora za djelovanje pomoću novoga zaduživanja, a tada im se zbog prezaduženosti spustio kreditni rating te im je zaduživanje postalo još skuplje. Ipak, u proteklom je desetljeću dobar dio zemalja Europske Unije uspio poraviti kreditni rejting, smanjiti kamatne stope i smanjiti javni dug, pa bi te zemlje krizu trebale dočekati lakše nego prije. $^{13}$ Zato će se u ovoj regresijskoj analizi nastojati provjeriti ima li i proračunska disciplina, u vidu kumulativa ranijih deficita, utjecaj na dužinu trajanja recesije. Za očekivati je da će zemlja s većim javnim dugom ostati duže u recesiji jer država tada ima znatno manji prostor djelovanja kako bi potakla domaću potražnju.

Treći je pokazatelj bruto domaći proizvod po stanovniku. Ovaj je pokazatelj zanimljiv jer se naoko može uočiti kako su bogatije zemlje brže izlazile iz krize premda u nekim slučajevima nisu imale značajnu prerađivačku industriju već su bili snažni u uslugama (Luksemburg. Malta)

Konačno, formiran je sljedeći model multiple linearne regresije:

$$
R E C_{i}=\beta_{0}+\beta_{1} P I_{i}+\beta_{2} J D_{i}+\beta_{3} W G I_{i}+\beta_{3} G P C_{i}+u_{i}
$$

gdje je REC broj recesijskih kvartala u razdoblju od 2007. - 2019., PI je udio prerađivačke industrije u BDP-u, JD je udio vanjskoga duga u BDP-u 2008 (godini početka krize), a WGI je indeks kvalitete upravljanja u 2008. godini. GPC je bruto domaći proizvod po stanovniku mjeren u tekućim eurima. Analizirani su podaci za sve zemlje Europske unije i Hrvatsku, a izvor podataka je Eurostat, Svjetska banka i Međunarodni monetarni fond. Ova regresijska analiza je analiza prostorne serije.

Nakon provedenih testova pokazatelj javnoga duga i kvalitete upravljanja i ekonomskih sloboda su značajni u modelu, a ponovnim se ocjenjivanjem modela bez nesignifikantnih varijabli dobio sljedeći model:

$$
\widehat{R E C}=23,3509-0,2748 P I-0,1474 W D I+0,0514 J D
$$

\footnotetext{
${ }^{13}$ Međutim, s obzirom na to da je epidemija daleko snažnije onemogućila ekonomsku aktivnost država članica, vlastite su se zalihe vrlo brzo potrošile pa se izlaz može očekivati tek u izdašnoj kasi Euopske Unije i fondu za pomoć koji iznosi 730 milijardi eura. Ipak, u ovom se radu nastoji izolirati ostale učinke utjecaja na pojavnost krize.
} 
Porast udjela prerađivačke industrije u BDP-u za 1 postotni poen smanjuje broj recesijskih kvartala u prosjeku za 0,27. Porast indeksa kvalitete upravljanja za 1 uzrokuje skraćenje trajanja recesije za 0,15 kvartala, a porast udjela javnoga duga u BDP-u za 1 postotni poen produžuje recesiju za 0,05 kvartala. Sve su vrijednosti parametara signifikantne, primijenivši jednostrani t-test za varijable PI i JD, dok je za WDI primijenjen dvostrani t-test. Odgovarajući testovi ukazuju na dobru formuliranost modela (jednosmjerni $t$ test za koeficijente i $\mathrm{F}$ test na razini značajnosti od $10 \%$ te odsustvo heteroskedastičnosti i multikonlinearnosti).

$\mathrm{Na}$ temelju dobivenih rezultata može se testirati hipoteza te se utvrđuje kako povećanje udjela prerađivačke industrije u BDP-u utječe na skraćivanje recesije. Pritom treba imati na umu kako je tek $27 \%$ varijabiliteta podataka objašnjeno modelom što ukazuje na to da su na duljinu trajanja recesije utjecali i drugi faktori. Isto tako, iznos koeficijenta od -0.27 pokazuje kako je za izlazak iz krize uz povećanje udjela prerađivačke industrije u BDP-u potrebno provoditi i druge mjere, uz ovdje spomenuto povećanje fiskalne discipline i povećanje kvalitete upravljanja.

Zanimljivost ovoga modela je u tome što je pomoću njega moguće predviđati duljinu trajanja recesije s obzirom na različitu početnu razinu javnoga duga, kvalitete upravljanja i ekonomskih sloboda te udjela prerađivačke industrije u BDP-u (EU28 bez Belgije). Tako se može utvrditi kako bi nova ekonomska kriza, bazirana na podacima netom prije početka epidemije COVID-19, trajala u prosjeku 10,17 kvartala, u odnosu na prethodnu koja je trajala 8,96 kvartala, što je $13,5 \%$ duže. I to bez utjecaja epidemije COVID-19. Ona će tek produbiti i pojačati ono što je Europsku Uniju, prema ovoj analizi, već čekalo. 27 promatranih zemalja

\section{ZAKLJUČAK}

Industrijska je proizvodnja važna karika u razvoju gospodarstva svake zemlje, a njezina je najvažnija komponenta prerađivačka industrija. Međutim ta se djelatnost zapustila u zemljama Europske Unije pod najezdom jeftinih proizvoda s Dalekog istoka, a taj proces traje više od pola stoljeća. Međutim iskustva Velike krize od 2008. - 2011. godine pokazala su da su zemlje s različitim stupnjem razvoja prerađivačke industrije različito reagirale na recesiju.

U prvom je dijelu ovoga rada dan pregled razvoja industrije u Europskoj Uniji, a posebno u Hrvatskoj, s analizom povijesnih uzroka trenutnoga stanja hrvatske industrije. U drugom su se dijelu rada analizirale sve članice EU28, osim Belgije, s obzirom na industrijalizacijski stadij, od ekspanzije (I. tip) sve do zamiranja i ponovnog buđenja (reindustrijalizacija, V. tip) metodologiji koju je utvrdio Levine (1991). Pokazalo se kako su zemlje Europske Unije vrlo heterogene s obzirom na industrijalizacijski tip. Stoga su i reperkusije krize i brzina izlaska iz krize različite u promatranim zemljama, a promjene koje su se događale u proteklih 20 godina su se različito odražavale na stabilnost i anticiklički karakter sektora prerađivačke industrije u tim zemljama.

U trećem dijelu je ekonometrijska analiza koja je pokazala da broj recesijskih kvartala za svaku pojedinu zemlju opada u slučaju većega udjela prerađivačke industrije 
u BDP-u, više razine kvalitete upravljanja i ekonomskih sloboda te nižeg javnog duga. Ocijenjeni ekonometrijski model je pokazao da bi kriza koja bi se eventualno dogodila i bez epidemije COVID-19, trajala $13,5 \%$ duže jer su zemlje manje spremne. U kombinaciji s epidemijom taj će ekonomski šok biti još teži.

\section{LITERATURA:}

1. An, Z., Jalles, J. T., Loungani, P. 2018. How well do economists forecast recessions? International finance, Vol. 21, Iss. 2

2. Campos, N. F., Coricelli F. 2000. Growth In Transition: What We Know, What We Don't, And What We Should. (April), WB Working Paper

3. Crkvenac, M. 1993. Ekonomika industrije i gospodarski razvoj Hrvatske. Informator. Zagreb.

4. Družić, I. et al. 1997. Razvoj i tranzicija hrvatskoga gospodarstva. Politička kultura. Zagreb.

5. Družić, I. et al. 2003. Hrvatski gospodarski razvoj. Politička kultura. Zagreb.

6. Družić, I. et al. 2004. Resursi i tržišta hrvatskog gospodarstva. Politička kultura. Zagreb.

7. El-Mattrawy, K.A. 2006. Total Factor Productivity, Human Capital, and the Growth Path of Egypt. Doktorska disertacija, Graduate Faculty of Political and Social Sciences, New School University, New York.

8. Hsieh, W.J. 2011. The Global Economic Recession and Industrial Structure: Evidence from Four Asian Dragons. ADBI Working Paper Series, No. 315 (October)

9. Jiang, X., Li, S., Song, X. 2017. The mystery of zombie enterprises - "stiff but deathless", China Journal of Accounting Research, Vol. 10, Iss. 4

10. Kratkov, A. 2011. The Great Recession Of 2008-2009 And Government's Role. Proceedings of ASBBS, Vol. 18, Las Vegas, USA., pp. 898 - 906.

11. Lever, W. F. 1991. Deindustrialisation and the Reality of the Post-industrial City. Urban Studies, Vol. 28, No. 6, Pp. 983-999.

12. Mencinger, J. 2012. Europe 2010 - A New Strategic Fantasy? Journal of Business\& Management, Vol. 3.

13. Mirković, M. 2001. Monografija. Prometej, Sveučilište u Zagrebu. Zagreb.

14. Möller J. 2010. Germany's Job Miracle in the World Recession-ShockAbsorbing Institutions in the Manufacturing Sector, Applied Economics Quarterly, Duncker \& Humblot, Berlin, vol. 61(Supplemen), pp 9-28.

15. Siddiqui, K. 2009. Japan's Economic Recession. Research in Applied Economics, Vol. 1, No. 1

16. Tomaševski, D. 2011. Reindustrijalizacija Hrvatske. Economics/ Ekonomija, vol. 18 , is. 2 , pp $365-376$

17. unstats.un.org/databases.htm, , pristupljeno 16. ožujka 2020. g.

18. wdi.worldbank.org, pristupljeno 16. ožujka 2020. g.

19. www.eurostat.eu, pristupljeno 16. ožujka 2020. g. 


\section{Dodatak}

Tablica 3. $\mathrm{t}$ i $\mathrm{F}$ test ocijenjenog modela.

\begin{tabular}{|l|l|l|l|l|}
\hline & MAN08 & PD08 & WDI08 & konstanta \\
\hline koeficijent & $-0,2405992$ & 0,0507588 & $-0,1420395$ & 22,52587 \\
\hline $\mathrm{t}$ vrijednost & $-1,43$ & 1,51 & 1,99 & 3,20 \\
\hline P vrijednost t testa & 0,084 & 0,072 & 0,029 & 0,002 \\
\hline $\mathrm{F}(3,23)$ & 2,62 & & & \\
\hline P vrijednost t testa & 0,0751 & & & \\
\hline $\mathrm{R}^{2}$ & 0,2547 & & & \\
\hline
\end{tabular}

Izvor: Izračun autora

Tablica 4. Korelacijska matrica regresora i regresanda.

\begin{tabular}{|l|r|r|l|l|}
\hline & \multicolumn{1}{|c|}{ REC } & \multicolumn{1}{c|}{ MAN08 } & WDI08 & PD08 \\
\hline REC & 1,0000 & & & \\
\hline MAN08 & $-0,2683$ & 1,0000 & & \\
\hline WDI08 & $-0,2969$ & $-0,1669$ & 1,0000 & \\
\hline PD08 & 0,2814 & $-0,1482$ & 0,1136 & 1,0000 \\
\hline
\end{tabular}

Izvor: Izračun autora

Tablica 5. Breusch-Paganov test o postojanju heteroskedastičnosti..

\begin{tabular}{|l|l|}
\hline B-P $\chi^{2}(1)$ & 0,08 \\
\hline P vrijednost $\chi^{2}$ testa (H0: ima heteroskedastičnosti) & 0,078 \\
\hline
\end{tabular}

Izvor: Izračun autora 


\title{
DEINDUSTRIALIZATION AND ITS EFFECT ON DAMPENING THE FUTURE CRISIS - A CASE OF EUROPEAN UNION
}

\author{
Tomislav Herceg
}

\begin{abstract}
Summary
In the European Union there is a long-term tendency of deindustrialization. This production gap was substituted with cheap goods from the overseas countries where salaries and working and environmental standards are much lower. A GDP gap was compensated with services sector. However, in this paper it was shown that, during recent Great economic crisis, the speed of recovery of the countries with stronger manufacturing was higher than in the countries with low manufacturing participation in GDP. An econometric model is built, showing how share of manufacturing in GDP of the countries of EU is negatively related to the length of recession in these countries: each 1\% point rise in that share shortnes crisis by 0,27 quarters. The model also included a composite governance quality index: each index point rise is related to the 0,15 recession quarters shortening. Also, countries' economic ability to interveine, measured as a share of public debt in GDP, showed that each 1\% point of public debt in GDP prolongues recession by 0,05 quarters. The analysis has also shown that, based on the initial conditions before the epidemics, the new risis would last 13,5\% longer than The great crisis. These findings provide useful ground for studying deindustrialization processes and its negative effects on the automatic stabilization, which is of utter importance for the imminent crisis caused by COVID-19 disease.
\end{abstract}

Key words: Manufacturing, European Union, Great Crisis, Worldwide Governance Indicators, Deindustrialization, COVID-19. 